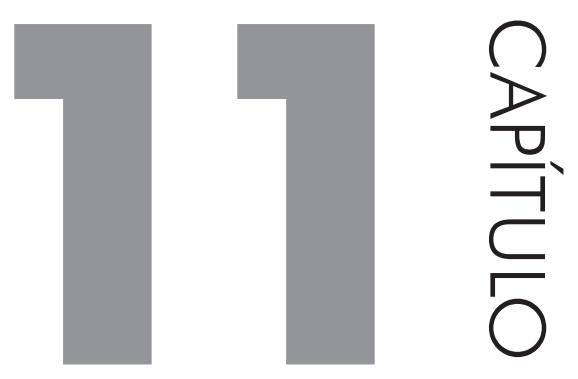

\title{
LICENCIATURA EM MATEMÁTICA A DISTÂNCIA - UFPE
}

\section{MARIA DO LIVRAMENTO SANTOS DA SILVA}

\section{LICENCIATURA EM MATEMÁTICA A DISTÂNCIA}

Meu nome é Maria do Livramento, sou Tutora presencial no polo Surubim do curso de Licenciatura em Matemática, desde 2010, a qual assumi a primeira turma considerada uma da pioneira em EAD pela UFPE.

Falar sobre minha experiência vivenciada no polo é superimportante, pois nesses anos de Tutoria passei por muitos momentos que marcaram minha trajetória e a dos discentes, como: angustias, dificuldades dos alunos na vida pessoal e acadêmica, a qual considero uma das vantagens de ser Tutor(a) presencial, pois conhecemos à fundo o nosso aluno (em todos os ângulos).

Estou acompanhando a terceira turma, as anteriores já concluíram e a grande maioria dos alunos está atuando nas escolas da cidade e cidades circunvizinhas. É muito prazeroso saber que nós, Tutores, contribuímos um pouco para o crescimento e sucesso profissional deles.

Um fato no qual não esqueço, e às vezes me pego a 'colorir aquela memoria', foi o de uma aluna que se encontrava em momentos difíceis em sua vida, devido a problemas decorrentes de inúmeros fatores que a levaram a aspectos depressi- 
vos, tornando o que antes era entusiasmo e alegria, em cinza pálido sem gana para seguir adiante com seus objetivos acadêmicos e de vida. Com as conversas diárias e ao empenho do restante dos alunos conseguimos reanima-la e traze-la a vida, ela chegou a conclusão o curso e hoje voltou a sala de aula. O elo tão estreito formado entre o Tutor e os alunos foi o impulso necessário para ela crescer novamente cada dia e voltar a sua lida. Não há recompensa maior para um educador que o ato de ajudar alguém a mudar sua vida para melhor. A essência do educador é esta: regar os pensamentos e vê-los crescer como uma planta, e a cada dia moldando seu próprio ser em busca de seu lugar ao sol. 